\title{
MUHAMMADIYAH URBAN: AKSELERASI GERAKAN MUHAMMADIYAH GRESIK KOTA BARU
}

\author{
Ahmad Nurefendi Fradana ${ }^{\mathrm{a}, 1^{*}}$, Akhmad Ahfas ${ }^{\mathrm{b}, 2^{*}}$ \\ ${ }^{\text {a, b }}$ Universitas Muhammadiyah Sidoarjo, Jl. Mojopahit 666-B, Sidoarjo 61215, Indonesia \\ 1'thefradana@umsida.ac.id*; ${ }^{2}$ ahfas@umsida.ac.id*
}

ARTICLE INFO

Article history:

Received : 2020-03-29

Revised : 2020-05-17

Accepted : 2020-06-18

Keywords:

Muhammadiyah Movement

Urban Society

\section{ABSTRACT}

This paper reveals the phenomenon that occurred in Muhammadiyah Gresik Kota Baru which, where there is a close relationship between Muhammadiyah and the middle class as the backbone of its movement. It is suspected that an accelerating move occurred in a relatively short time, Muhammadiyah Gresik Kota Baru increased rapid progress. One of the dynamics of Indonesian society that is considered important to be observed is the existence of a slow but sure shift to the sociological conditions and the religiosity of the community. Then created a group of people who came to be called the middle class. This middle class is knowledgeable, highly educated, well-established and open-minded. The next stage, they are determined as: Urban society. Since its inception, Muhammadiyah as a religiously based community organization has ties for the whole community. Muhammadiyah always undertakes multi-step revitalization of its dakwah. These efforts have so far been carried out regularly and regularly and touches almost all layers of society as objects (and subjects) of their missionary movements. This group of people is no exception: Urban society.

\section{ABSTRAK}

Tulisan ini mengungkap fenomena yang terjadi di Muhammadiyah Gresik Kota Baru yang mana, di mana terdapat hubungan erat Muhammadiyah dan masyarakat kelas menengah sebagai penopang gerakannya. Ditengarai, terjadi akselerasi yang bergerak dalam waktu yang relatif singkat, Muhammadiyah Gresik Kota Baru meningkatkan kemajuan yang cepat. Salah satu dinamika masyarakat Indonesia yang dipandang penting untuk diamati adalah adanya pergeseran yang perlahan namun pasti terhadap kondisi sosiologis dan religiositas komunitas masyarakat. Lalu terciptalah satu golongan masyarakat yang kemudian disebut sebagai kelas menengah. Kelas menengah ini berpengetahuan luas, berpendidikan tinggi, berpenghasilan mapan, dan berpikiran terbuka. Tahap selanjutnya, mereka ditetapkan sebagai: Masyarakat urban. Sejak awal, Muhammadiyah sebagai organisasi masyarakat yang berbasis religius memiliki ikatan untuk seluruh komunitas. Muhammadiyah senantiasa melakukan revitalisasi multi-langkah dakwahnya. Upaya tersebut sejauh ini dijalankan secara ajek dan teratur serta menyentuh hampir seluruh lapisan golongan masyarakat sebagai objek (dan subjek) gerakan dakwahnya. Golongan masyarakat itu tak terkecuali: Masyarakat urban. 


\section{Pendahuluan}

Sejak awal didirikan oleh KH Ahmad Dahlan, Muhammadiyah rasanya dirancang sebagai gerakan pencerahan. Dakwah pencerahan yang digagas oleh $\mathrm{KH}$ Ahmad Dahlan itu bukan hanya berhenti pada perkara ibadah mahdhah saja semisal salat, puasa, zakat, dan sebagainya. Muhammadiyah juga menaruh perhatian serius pada persoalan-persoalan yang menyangkut dinamika sosial masyarakat. Maka, tidak terlalu mengherankan jika pada masa awal berdirinya, Muhammadiyah banyak mendirikan amal usaha berupa sekolah rakyat, panti sosial, hingga gerakan menyantuni fakir miskin-anak yatim.

Namun secara sosiologis, pada dimensi tertentu, gerakan Muhammadiyah agak susah untuk tidak diakui sebagai "gerakan kelas menengah". Mayoritas penyokong Muhammadiyah pada masa-masa awal juga banyak yang berasal dari kelas menengah. Bahkan jika menilik sejarah, sesungguhnya KH Ahmad Dahlan sendiri juga berasal dari golongan kelas menengah: Beliau berlatar belakang keluarga terpandang di Kauman, Yogyakarta, terpelajar, dan seorang pedagang yang cukup sukses. Para pendukung di sekitar beliau juga banyak yang berlatar kaum pedagang dan kaum terpelajar.

PP Muhammadiyah (2015) memberikan pengertian terhadap istilah "kelas menengah" ini sebagai kelas sosial yang di dalamnya berisi mereka yang telah mapan. Umumnya berprofesi sebagai dosen, PNS, hingga pengusaha. Rata-rata kondisi sosial ekonomi mereka sudah cukup dan tidak kekurangan. Selain itu, tingkat pendidikan mereka juga tergolong tinggi.

PP Muhammadiyah (2015) secara rinci memotret masyarakat kelas menengah ini dengan memaparkan bahwa kelas sosial ini selain memiliki profesi yang beragam, sekaligus juga memiliki karakter kolektif yang serupa. Pertama, mereka sudah mapan dan berkecukupan secara ekonomi untuk memenuhi kebutuhan hidup secara layakmeskipun masih harus dengan tetap bekerja. Kedua, mereka memiliki kecenderungan akomodatif terhadap sikap politik, oleh sebab mereka berada di tengah-tengah antara kelompok elit dan kelompok bawah.
Ketiga, mereka dinamis secara sosial, dalam pengertian memiliki kesempatan untuk berkembang menjadi bagian kelompok elit atau-bahkan-bisa turun menjadi bagian dari kelompok bawah. Keempat, mereka bersifat populer secara budaya, yakni mencoba menduplikasi perilaku kelompok elit, namun berupaya menyesuaikan diri dengan kemampuan ekonomi yang mereka miliki. Kelima, mereka reformis secara agama, dalam pengertian mereka akan sangat mendukung perubahan dan perbaikanperbaikan individu maupun sosial.

Sucipto (2010: 13) berpandangan bahwa, karakter Islam yang menjiwai sikap tajdid (pembaruan) sudah demikian melekat pada Muhammadiyah sejak awal didirikan. Karakter ini dipegang teguh oleh seluruh elemen Muhammadiyah dari pusat hingga masis massanya. Hal ini senada dengan apa yang disebut oleh Haedar Nashir (2010), bahwa saham dari masyarakat tradisional menuju kebudayaan masyarakat modernis inilah yang senantiasa ditampilkan oleh Muhammadiyah.

Lebih lanjut, Kuntowijoyo (2006) mengidentifikasi, masyarakat kelas menengah baru adalah sekelompok orang yang memiliki status sosial, bertempat tinggal di lingkungan tertentu, dan mudah menerima serta melakukan pembaruan. Kebanyakan dari anggota masyarakat kelas menengah baru baru adalah penduduk perkotaan yang mempunyai status sosial sebagai pedagang, pegawai industri, golongan terpelajar guru dan dosen, dan lain sebagainya. Kaum intelektual selalu berada pada posisi yang paling depan dalam pembentukan sistem pengetahuan dan perubahan masyarakat.

Mengenai dinamika masyarakat urban, Kuntowijoyo (2000) memiliki pandangan bahwa ketika masyarakat perkotaan menggeser peranan komunitas pedesaan sebagai aktor perubahan yang hal ini dipandang sebagai salah satu fenomena penting dalam perjalanan sejarah masyarakat Indonesia. Di sini terjadi kebangkitan golongan kelas menengah. Kelas menengah baru ini terdiri dari atas kaum pengusaha dan cendekiawan yang menguasai cakrawala kehidupan perkotaan. 
Kajian mengenai pergerakan Islam dipadu dengan dinamisasi masyarakat urban amat menarik untuk dikaji. Mengingat, kondisi sosial-politik masyarakat Indonesia yang belakangan sudah mulai ada tanda-tanda adanya kebangkitan komunitas masyarakat urban perkotaan. Kehadiran mereka kinisemacam menjadi salah satu penopang dalam proses pembangunan suatu kota. Sehingga, barangkali isu menarik ini dapat memberi sumbangsih pada kajian-kajian mengenai agama dan masyarakat urban (serta relasinya).

Penelitian terdahulu yang berkaitan dengan dinamika pergerakan Muhammadiyah dapat dibaca misalnya kajian yang dilakukan oleh Ahmad Najid Burhani. Dalam bukunya, "Muhammadiyah Jawa", Ahmad Najib Burhani menjadikan Keraton Yogyakarya sebagai bahan ulasan pokok kajiannya. Yang, dalam konteks sosiologis, amat berhubungan erat dengan kelahiran Muhammadiyah. Kajian historiografi ini pada akhirnya memotret pengaruh Jawa terhadap cara $\mathrm{KH}$ Ahmad Dahlan memandang Islam dan pengamalannya.

Melalui penelitiannya ini, Ahmad Najib Burhani (2010) menggambarkan pandangan dan sikap Muhammadiyah terhadap budaya Jawa. Ia merinci bahwa pilar utama penyokong pergerakan Muhammadiyah pada masa-masa awal berdirinya didominasi priyayi dan santri Kauman, Yogyakarta. Bahkan, dalam upaya untuk mengapresiasi kebudayaan Jawa-sebagai tempat berdirinya Muhammadiyah - ditekankan lima aspek, diantaranya cara berperilaku, tutur bahasa, tata cara berbusana, aspek keanggotaan, dan penggunaan istilah-istilah di Muhammadiyah pada masa itu.

Selain itu, riset yang dilakukan oleh Mustakim bertajuk "Matahari Terbit di Kota Wali: Sejarah Pergerakan Muhammadiyah Gresik 1926-2010" juga menarik. Mustakim mencoba mengumpulkan serpihan-serpihan sejarah Muhammadiyah kabupaten Gresik. Dijelaskan bahwa Muhammadiyah Gresik merupakan organisasi yang hadir dalam rangka untuk membangkitkan kesadaran umat dari keterbelakangan dan kebodohan.

Dalam konteks ini, ia menjelaskan bahwa disatu sisi, Muhammadiyah menginginkan pembaruan dan menjadi gerakan ijtihad untuk menghadapi perkembangan masyarakat kota. Di sisi lain, terdapat kelompok Nahdhatul Ulama' (NU) yang berbasis masyarakat pedesaan sebagai kelompok Islam yang tradisional. Mayoritas masyarakat Gresik beragama Islam, tetapi secara kualitas tingkat pemahaman dan ketaatan dalam menjalankan Islam berbedabeda.

Lebih lanjut, ia membagi dua kelompok masyarakat Islam di Gresik yang berbeda dari segi kedalaman, pemahaman, dan ketaatan dalam Islam. Kelompok pertama ialah masyarakat Gresik utara yang umumnya memiliki kesadaran agama yang kuat. Pada masyarakat ini otoritas karismatik ada kepada kiai, sedangkan masyarakat yang berada di Gresik selatan memiliki kesadaran keberagamaan yang lemah (Mustakim, 2011).

Oleh karena itu, Muhammadiyah hadir dan memfokuskan gerakannya pada bidang pendidikan, sosial, dan kesehatan, yakni membawa teologi al-ma'un yang menjadi ciri Muhammadiyah.

\section{Tinjauan Pustaka}

\section{A. Potret Muhammadiyah Gresik Kota Baru}

Gresik Kota Baru sesungguhnya adalah nama kompleks perumahan yang terletak di dua kecamatan, yakni "irisan" antara Kebomas dengan Manyar, Kabupaten Gresik, Jawa Timur. Gresik Kota Baru adalah pemukiman baru di kota Gresik. Dalam kurun waktu yang tidak terlalu lama, kondisi kepadatan penduduk di lingkungan yang baru ini mengalami perkembangan yang cukup pesat.

Oleh karena terjadinya proses pergeseran masyarakat industri inilah, maka terjadilah urbanisasi secara besar-besaran. Akibatnya adalah mendesak akan kebutuhan pemukiman baru untuk masyarakat. Permasalahan inilah yang kemudian direspon oleh Pemerintah Kabupaten Gresik dengan melakukan pengembangan kawasan pemukiman-yang kemudian disebut "Gresik Kota Baru". PT Bumi Lingga Pertiwi-yang dimiliki oleh begawan simpatisan Muhammadiyah, H. Bisri sebagai 
pengembang kawasan ini (Berkah dan Khoirudin, 2014).

Boleh jadi, ini memang sebuah titik temu Muhammadiyah dengan kelas menengah baru. Muhammadiyah yang identik dengan modernis bersinggungan dengan kelompok masyarakat baru. Sehingga dengan cepat menjadi pusaran energi dakwah. Secara ideologis selain mereka pernah bermuhammadiyah juga memang secara sosial sesuai dengan doktrin Muhammadiyah, Hal inilah yang dinilai mampu membentuk kelompok umat akan menghasilkan pusaran energi dakwah yang luar biasa di Muhammadiyah cabang GKB (Berkah dan Khoirudin, 2014).

Menurut PCM GKB (2000), gagasan didirikannya Pimpinan Cabang Muhammadiyah Gresik Kota Baru adalah pelbagai kegiatan dakwah Islam, pendidikan dan sosial kemasyarakatan Muhammadiyah di lingkungan Gresik Kota Baru dan sekitarnya, saat itu ditangani oleh "Pengurus Jama'ah Muham-madiyah GKB" yang masuk dalam kawasan wilayah Muhammadiyah Kebomas yang dalam perkembangannya, intensitas dan volume kegiatan keislaman di wilayah GKB dirasakan semakin tinggi, sehingga memerlukan perhatian dan perangkat yang lebih besar.

Maka pada akhirnya, lain dari lazimnya Pimpinan Cabang Muhammadiyah yang berdiri berdasarkan geografis kecamatanatau gabungan beberapa desa, Pimpinan Cabang Muhammadiyah Gresik Kota Baru berdiri merujuk pada sebuah pemukiman perumahan yang merupakan "irisan" antara Kecamatan Kebomas dengan Kecamatan Manyar (Berkah dan Khoirudin, 2014). Pun demikian dengan Pimpinan Rantingnya, yakni pembagian jalan dan gang yang berada di lingkungan perumahan dengn nomenklatur Pimpinan Ranting Muhammadiyah GKB 1, 2,3 , dan seterusnya.

\section{B. Masyarakat Urban}

Urbanisasi pada gilirannya menciptakan kota-kota baru yang memiliki magnet kuat terhadap pembangunan masyarakat. Selain itu, dinamika ini dapat pula memacu-dan memicu pertumbuhan dan perkembangan ekonomi bagi masyarakat itu sendiri (Harahap, 2013).
Secara sosiologis, masyarakat urban memiliki potensi yang cukup kuat untuk melakukan perubahan. Dinamika yang entah dibuat atau memang secara alamiah tercipta merupakan modal besar untuk lahirnya perbaikan-perbaikan pada diri anggota masyarakat.

Sebagai komunitas, masyarakat urban memiliki potensi untuk saling bersinergi membangun suatu cita-cita bersama. Sebab masing-masing dari mereka yang memiliki kemampuan yang mumpuni untuk terjadinya perubahan masyarakat secara luas-baik radius maupun dampaknya - dan cepat, aspek inilah yang mengakibatkan pertumbuhan masyarakat urban di berbagai tempat di Indonesia amat banyak jumlahnya.

Lebih lanjut, Harahap (2013) memaparkan, urbanisasi dipicu oleh adanya perbedaan pertumbuhan atau ketidakmerataan fasilitas-fasilitas dari pembangunan, khususnya antara daerah pedesaan dan perkotaan. Akibatnya, wilayah perkotaan menjadi magnet menarik bagi kaum urban untuk mencari pekerjaan.

\section{Muhammadiyah dan Masyarakat Urban}

Perbincangan tentang Muhammadiyah telah banyak dilakukan para peneliti maupun para penulis, baik dari dalam maupun peneliti luar negeri. Perbincangan yang dilakukan meliputi pelbagai aspek dan pendekatan, mulai dari tinjauan sejarah keberadaannya, kajian pemikiran keagamaannya, kajian tokoh-tokoh pendiri dan pemimpinnya, kajian aspek politik, kajian aspek pendidikan, dan sebagainya. Kajian-kajian tersebut banyak dilakukan oleh orang luar (the outsider) maupun dari dalam (the insider), yaitu orang Muhammadiyah sendiri (Hidayat, 2012).

Pada saat gaya hidup sebagian besar masyarakat kita yang serba-materialistik dalam peradaban global industrial ini, tibatiba muncul gagasan baru mengenai aspek spiritual yang memicu kesadaran baru secara besar-besaran. Logika masyarakat global industrial yang memberhalakan ekonomi dan teknologi yang nyaris mengabaikan aspek rohani, ternyata muncul masyarakat kelas menengah baru yang memiliki kesadaran yang cukup tinggi terhadap hal pemahaman 
terhadap wilayah-wilayah spiritual (Mulkhan, 2010: 21).

Suatu hal yang memberikan energi positif bagi kita ialah, bahwa Indonesia diprediksi pada tahun 2025 akan menyumbang 145 juta warga kelas menengah baru untuk dunia, dimana pada tahun ini, kelas menengah Indonesia bisa mencapai angka 50 juta. Dengan kekuatan ekonomi Indonesia, dipastikan menjadi awal kekuatan ekonomi nasional. Hal ini harus disikapi dan direspon secara baik oleh Muhammadiyah. Jika Muhammadiyah sebagai gerakan tajdid, maka sudah tentu harus selalu responsif dengan realitas yang terus berkembang dan berubah dengan begitu cepat (Khoirudin, 2013).

Maka, sudah barang tentu, Muhammadiyah sebagai civil society, juga memiliki tanggung jawab secara serius perkara perkembangan masyarakat urban ini. Keberadaan Muhammadiyah sebagai organisasi masyarakat sejauh ini cukup memberi pengaruh aktivitas keberagamaan masyarakat kelas menengah ini dalam dosis yang relatif cukup tinggi.

\section{Metodologi Penelitian}

Pendekatan yang dilakukan oleh penelitian ini adalah pendekatan kualitatif. Prosedur penelitian yang menghasilkan datadata berupa deskripsi berbentuk kata-kata tertulis dapat dimaknai sebagai penelitian kualitatif (Moleong, 2005).

Sedangkan Nazir (1983) mengatakan bahwa, "Penelitian deskriptif adalah suatu metode penelitian tentang kelompok manusia, suatu objek, suatu kondisi, suatu sistem pemikiran ataupun suatu kejadian pada masa sekarang." Oleh sebab itu, peneliti meyakini bahwa metode ini tepat untuk meneliti akselerasi gerakan Muhammadiyah Gresik Kota Baru.

Sedangkan, teknik pengumpulan data yang dilakukan dalam kegiatan penelitian ini ialah: library research (penelitian kepustakaan) dan field research (penelitian lapangan). Sedangkan, pengumpulan data dilakukan dengan observasi lapangan, wawancara dengan pihak-pihak terkait, dan dokumentasi. Hingga pada akhirnya, proses pengolahan data dilakukan dengan urutan:
Mereduksi data, menyajikan data, dan menarik kesimpulan.

\section{Hasil dan Diskusi}

\section{A. Bermula dari Kompleks Perumahan}

Gresik Kota Baru yang selanjutnya disebut dengan GKB, dimana GKB merupakan kawasan pemukiman baru yang awalnya sebuah perbukitan, tegalan, dan tempat pemakaman Cina. Selain itu, juga menjadi tempat pembakaran batu gamping atau kapur yang terletak di wilayah selatan Desa Randuagung Kecamatan Kebomas, yang sekarang meluas sampai Desa Kembangan (termasuk Kecamatan Kebomas) dan Kecamatan Manyar yang meliputi Desa Yosowilangun, yang kemudian berkembang ke Desa Sukomulyo, Desa Suci, dan Pongagan (Khoirudin dan Berkah, 2013: 35).

GKB merupakan nama sebuah kompleks hunian baru di Kabupaten Gresik yang dalam kurun waktu yang tidak terlalu lama memiliki tingkat kepadatan penduduk yang cukup tinggi. Perkembangan pesat Perumahan GKB ini ditunjang oleh para penghuninya yang mayoritas adalah pendatang. Proses urbanisasi inilah yang pada gilirannya melahirkan komunitas masyarakat yang bisa disebut sebagai masyarakat urban.

Akhirnya, terbentuklah peradaban baru dan masyarakat berkebudayaan baru yang di dalamnya bercampur adat dan kebiasaan yang dibawa dari daerah asal yang berbedabeda. Disinilah terjadinya pertemuan antara Muhammadiyah dengan masyarakat urban. Titik temu antara Persyarikatan - sebagai gerakan modernis dengan masyarakat kelas menengah yang juga berpola pikir modernterbuka itu. Terjadilah akselerasi gerakan Muhammadiyah yang dikelola oleh masyarakat urban ini.

\section{B. Tumbuh Berakar Pengajian}

Sebagai gerakan dakwah, pengajian adalah salah satu nafas utama Persyarikatan Muhammadiyah. Hampir dapat dipastikan, gerakan Muhammadiyah di akar rumput biasanya ditopang kokoh oleh kegiatan pengajian oleh para penggeraknya. Berbagai model pengajian di Muhammadiyah telah berkembang - mulai dari bulanan, hingga yang populer belakangan: Ahad pagi. 
Kesemuanya itu adalah bentuk ikhtiar Muhammadiyah membumikan dakwah Islam.

Khoirudin dan Berkah (2013) menerangkan, pada awal mulanya, di salah satu kawasan RT 27 dan RW 06 Desa Randuagung Kecamatan Kebomas tepatnya di Jl. Kutai terdapat dua orang aktivis Muhammadiyah

yang berasal dari Gresik bagian utara, yakni Taufik Hadi dan Agus Ibrahim yang secara kebetulan mereka bertetangga. Naluri berMuhammadiyah menjadikan mereka ingin berdakwah dengan menyelenggarakan pengajian. Hal tersebut dilontarkan kepada tetangga mereka saat jaga ronda malam atau siskamling, akhirnya mendapatkan respons positif. Kemudian kedua orang tersebut mengumpulkan orang untuk bermusyawarah di rumah Agus Ibrahim.

Dalam rapat tersebut, disepakati nama pengajiannya yaitu "Pengajian Agama Islam Al-Muhajirin". Nama Al-Muhajirin mengandung makna filosofis sebagai kelompok umat yang berhijrah, yaitu dari pergeseran pusat kota dari kecamatan Gresik menuju perumahan Gresik Kota Baru. Situasi masa Orde Baru, mengakibatkan banyak teror yang dilakukan oleh warga tentang keberadaan pengajian Al-Muhajirin. Kelompok ini dituduh dan diisukan ilegal, sehingga perlu dibubarkan.

Pada akhirnya, pengajian pun sempat dibubarkan, namun berhasil membuat lagi yang kemudian ditempatkan di rumah Pak Yamin, yang diasuh oleh Kiyai Muhith. Pengajian ini dipelopori oleh M. Yamin, Agus Ibrahim, Taufik Hadi Syarief, dan Soenaryo Anwar. Mereka inilah yang menghubungi Kiyai Muhith di Desa Keramat, Kecamatan Duduksampean. Meskipun dengan medan atau jalan yang terjal, jika hujan tidak bisa dilewati dengan sepeda, kecuali harus mendorong sepeda. Dengan niat ihlas, dakwah Islam amar makruf nahi munkar, maka semua menjadi ringan dan menyenangkan.

Pada akhirnya, gerakan pengajian inilah yang menjadi embrio berdirinya Pimpinan Cabang Muhammadiyah Gresik Kota Baru.

\section{Berdirinya "Muhammadiyah Urban"}

Gerakan Muhammadiyah Cabang GKB dimulai dengan melakukan pembentukan ranting yang waktu itu hanya ada tiga ranting. Pertama, Ranting GKB I: Jl. Cimanuk, Jl. Raya Brantas, Jl. Randuagung Raya, Jl. Sungai Asahan, Jl. Raya Sungai Bengawan Solo, J1. Dr. Wahidin Sudirohusodo (Balai Desa ke Barat), Jl. Sungai Serayu, Jl. Sungai Mahakam, Jl. Sungai Kampar, Jl. Sungai Kahayan, Jl. Sungai Kutai, dan Jl. Simpang Sungai Bengawan Solo. Kedua, Ranting II: Jl. Raya Brantas (Cimanuk ke Timur), Jl. Taman Brantas, Jl. Dr Wahidin Sudirohusodo ke Timur, Jl. Sungai Musi, Jl. Sungai Citanduwi, Jl. Sungai Cisedia, Jl. Sungai Ciliwung, Jl. Sungai Cisadea, dan Jl. Kampuas. Ketiga, Ranting III: Jl. Blitar, Jl. Sumatra, Jl. Jawa, Jl. Bangka, Jl. Belitung, Jl. Mentawai, Jl. Sumbawa, Jl. Bintan, Jl. Bintan, Jl. Karimun, Jl. Taman Enggano, Jl. Nias, Jl.Lamongan, Jl. Bondowoso, dan Jl. Malang (Berkah dan Khoirudin, 2013: 80).

Pendirian Pimpinan Cabang Muhammadiyah Gresik Kota Baru (PCM GKB) terbilang cukup unik. Lazimnya, sebuah pimpinan cabang Muhammadiyah biasanya didirikan mengacu berdasarkan Kecamatan - secara administratif. Akan tetapi, PCM GKB berdiri di atas irisan dua kecamatan, yakni Kecamatan Kebomas dan Kecamatan Manyar (Perumahan GKB berada di irisan dua Kecamatan ini). Begitu pula dengan pimpinan ranting, sebab komunitas Muhammadiyah ini berada di lingkungan perumahan, nomenklatur yang digunakan juga unik. Yakni Pimpinan Ranting Muhammadiyah GKB I, GKB II, GKB III, dan seterusnya.

Setelah sebelumnya berkegiatan dan eksis sebagai "Muhammadiyah komunitas", pada tahun 2000 PCM GKB kemudian meresmikan diri. Yakni ditetapkannya Pimpinan Cabang Muhammadiyah Gresik Kota Baru oleh Pimpinan Wilayah Muhammadiyah Jawa Timur dengan Ketua pertama Taufiq Hadi. Pada tahap selanjutnya, PCM GKB semakin berkibar dengan berdirinya beberapa amal usaha. 


\section{Perkembangan Pesat Muhammadiyah Gresik Kota Baru}

Kemunculan Muhammadiyah Gresik Kota Baru sesungguhnya tak lain adalah bukti bahwa Muhammadiyah demikian erat menjalin hubungan dengan masyarakat urban atau masyarakat kelas menengah. Muhammadiyah yang berciri modern dan berwawasan terbuka, sebagai gerakan tajdid yang modern menjadi semacam basis wadah berkumpulnya para "manusia urban" untuk berekspresi dan berorganisasi. Hal ini bukan berarti Muhammadiyah abai terhadap basis masyarakat non-urban - misalnya kaum mustadz'afin dan tertindas. Muhammadiyah tetap memberi perhatian kepada mereka, sebagai salah satu bagian dari jamaahnya.

Tetapi nyatanya, Muhammadiyah di kalangan masyarakat urban ini dapat dengan cepat - dan amat pesat berkembang berdasarkan uraian pada bab terdahulu, disebabkan oleh berbagai faktor. Nah, salah satu fator utamanya adalah kondisi sosialekonomi masyarakat urban yang umumnya mapan. Rata-rata mereka berpendidikan tinggi, juga memiliki pekerjaan yang relatif baik. Mereka sudah tidak lagi terlalu disibukkan dengan urusan dapur dan rumah. Persoalan hidup mereka umumnya sudah "selesai", sehingga dengan demikian, Muhammadiyah di tangan mereka tidak lagi dikelola secara sambil lalu dan "amatiran". Selain itu, pola pikir mereka yang demikian terbuka menjadikan pengelolaan organisasi menjadi modern sehingga berkembang pesat.

\section{E. Akselerasi Gerakan Muhammadiyah Gresik Kota Baru}

Pimpinan Cabang Muhammadiyah Gresik Kota Baru yang relatif baru-berdiri tahun 2000 telah melakukan upaya-upaya akselerasi gerakan. Hal ini ditandai dengan berdirinya amal usaha-amal usaha yang terbilang cukup berkualitas dalam menjalankan misi Persyarikatan Muhammadiyah. Misalnya, lembaga pendidikan yang dikelola oleh Pimpinan Cabang Muhammadiyah Gresik Kota Baru memiliki kualitas yang baik mulai dari SD Muhammadiyah GKB I, SD Muhammadiyah GKB II, SMP Muhammadiyah 12 GKB, hingga SMA Muhammadiyah 10 GKB. Kesemuanya menjelma menjadi sekolah- sekolah unggulan tingkat Muhammadiyah Jawa Timur. Kendati pun belum terlalu lama berdiri.

Hanya dalam kurun waktu 20 tahun sejak berdiri, waktu yang relatif singkat bagi sebuah pergerakan dengan aneka amal usaha yang besar dengan jumlah aset yang tidak kecil, Pimpinan Cabang Muhammadiyah Gresik Kota Baru menjelma menjadi Cabang Muhammadiyah unggulan bahkan di tingkat Jawa Timur. Tak jarang, Pimpinan Cabang Muhammadiyah lain datang dari berbagai tempat untuk menimba ilmu manajemen pengelolaan organisasi dan amal usaha.

Sehingga, pada ajang Cabang dan Ranting Muhammadiyah Expo (CRME) $2019 \mathrm{di}$ Limbung Gowa Sulawesi Selatan (Sulsel), Pimpinan Cabang Muhammadiyah Gresik Kota Baru dinobatkkan sebagai Juara II Cabang Unggulan tingkat nasional.

Tak dapat dimungkiri, adanya akselerasi gerakan di Pimpinan Cabang Muhammadiyah Gresik Kota Baru adalah wujud dari adanya sumber daya manusia yang memadai untuk kemajuan Muhammadiyah GKB yang demikian pesat. Sumber daya manusia yang memadai-atau unggul itulah yang menjadi penopang utama (sekaligus lokomotif) gerakan dakwah Muhammadiyah di Gresik Kota Baru. Muhammadiyah, sebagaimana gerakangerakan yang lain, membutuhkan sumber daya manusia unggul untuk menjalankan misinya, tanpa adanya sumber daya manusia yang unggul, boleh jadi pergerakan Muhammadiyah akan melambat, stagnan, atau bahkan mengalami kemunduran.

Selain itu, karena berada di lingkungan perumahan, Muhammadiyah Gresik Kota Baru "diuntungkan" oleh lingkungan yang tertata - sebagaimana perumahan pada umumnya. Nyaris tidak ada problem sosial yang berarti. Sehingga, perkembangan Muhammadiyah yang demikian pesat itu, sangat mungkin oleh karena kondisi lingkungan sosialnya yang sudah "terkondisikan". Jadi, karena sumber daya manusia yang memadai sudah tersedia, dipadu dengan kondisi lingkungan sosial yang tertata, terjadilah akselerasi gerakan di sini. 


\section{F. Kultur Masyarakat Urban}

Soekanto (2006) memaparkan, sesungguhnya ada perbedaan yang pada hakikatnya bersifat gradual antara masyarakat desa dengan masyarakat kota. Perbedaan ini pada titik tertentu agak susah diidentifikasi oleh karena tidak setiap hasil proses urbanisasi dapat disebut sebagai komunitas masyarakat perkotaan - bahkan masyarakat urban. Sehingga pada akhirnya, perbedaan antara masyarakat pedesaan dan perkotaan menjadi sulit untuk dirumuskan.

Akan tetapi, setidaknya, pengertian masyarakat urban dapat dirumuskanmisalnya dengan memperhatikan aspek kemajuan yang terjadi, aspek perubahan sosial yang berjalan, hingga aspek dinamisasi yang dihasilkan oleh komunitas masyarakat itu.

Masyarakat urban adalah makhluk sosial yang membutuhkan manusia lain dalam kehidupannya, sekelompok manusia yang saling membutuhkan tersebut akan membentuk suatu kehidupan bersama yang disebut dengan masyarakat. Masyarakat itu sendiri dapat didefinisikan sebagai suatu kesatuan hidup manusia yang berinteraksi sesuai dengan sistem adat istiadat tertentu yang sifatnya berkesinambungan dan terikat oleh suatu rasa identitas bersama (Soekanto, 2006).

Masyarakat urban sering dicirikan sebagai masyarakat modern. Adapun ciri-ciri masyarakat ini menurut Mutakin (2004), antara lain: 1) Hubungan antar-sesama nyaris hanya didasarkan pada pertimbangan untuk kepentingan pribadi; 2) Hubungan dengan masyarakat lain berlangsung secara terbuka dan saling memengaruhi; 3) Menyakini bahwa IPTEK memiliki kemanfaatan untuk meningkatkan kualitas hidupnya; 4) Masyarakat kota berdeferensi atas dasar perbedaan profesi dan keahlian sebagai fungsi pendidikan serta pelatihan; 5) Tingkat pendidikan masyarakat kota relatif lebih tinggi bila dibandingkan dengan masyarakat pedesaan; 6) Aturan-aturan atau hukum yang berlaku dalam masyarakat perkotaan lebih berorientasi pada aturan atau hukum formal yang bersifat kompleks; 7) Tata ekonomi yang berlaku bagi masyarakat kota umumnya ekonomi pasar yang berorientasi pada nilai uang, persaingan, dan nilai-nilai inovatif lainnya; dan 8) Kehidupan keagamaannya berkurang, kadangkala tidak terlalu dipikirkan karena memang kehidupan yang cenderung kearah keduniaan saja.

Muhammadiyah Gresik Kota Baru didirikan, dikelola, dan dikembangkan oleh mereka-yang disebut sebagai masyarakat urban. Ciri utama jenis masyarakat ini adalah berpola pikir terbuka, cerdas, dan maju. Sedangkan, sejak awal, Muhammadiyah lahir dari pikiran-pikiran terbuka-cerdas-maju dari sang pendiri, KH Ahmad Dahlan. Jadi, sesungguhnya, pada dasarnya, Muhammadiyah Gresik Kota Baru yang berkembang sedemikian pesat tak lain adalah adanya "pertemuan" kedua sumbu ini: Muhammadiyah sebagai gerakan modern, dan masyarkat Gresik Kota Baru sebagai masyarakat urban yang modern.

\section{Kesimpulan}

Proses urbanisasi besar-besaran mengakibatkan terjadinya pergeseran masyarakat urban. Sehingga, membuka lebar kemungkinan mereka berkumpul pada satu basis sosial yang sama berupa pemukiman sehingga aktivitas sosial-religius mereka dapat disatukan pula. Adanya Pimpinan Cabang Muhammadiyah Gresik Kota Baru merupakan implikasi dari pergeseran masyarakat urban ini.

Sebagai kelas sosial, masyarakat urban yang memiliki ciri utama modern, terpelajar, dan mapan memiliki peran membuat pergerakan Muhammadiyah Gresik Kota Baru berkembang amat dinamis melampaui pergerakan Muhammadiyah pada umumnya. Pimpinan Cabang Muhammadiyah Gresik Kota Baru melakukan dinamisasi gerakan yang terbilang amat cepat. Didirikan sejak tahun 2000, mereka sudah memiliki berbagai amal usaha yang terbilang maju.

Kultur masyarakat urban yang terbukacerdas-maju bertemu dengan Muhammadiyah yang didirikan atas dasar pemikiran terbuka-cerdas-maju oleh $\mathrm{KH}$ Ahmad Dahlan pada dasarnya merupakan gambaran adanya "pertemuan" dua sumbu yang sesungguhnya saling bersinggungan ini. Keberadaan Pimpinan Cabang Muhammadiyah Gresik Kota Baru sebagai "produk" masyarakat urban menjadi semacam pembuktian bahwa gerakan Muhammadiyah dapat berkembang dengan 
pesat dan signifikan meskipun dalam kurun waktu yang relatif singkat di tangan masyarakat maju dan modern.

\section{Daftar Pustaka}

A. Mutakin. (2004). Dinamika Masyarakat Indonesia. Bandung: Genesindo.

Abdul Munir Mulkhan. (2010). Pesan dan Kisah Kiai Ahmad Dahlan dalam Hikmah Muhammadiyah. Yogyakarta: Suara Muhammadiyah.

Ahmad Najib Burhani. 2010. Muhammadiyah Jawa. Jakarta: Al-Wasath.

Azaki Khoirudin. (2014). Muhammadiyah dan Kelas Menengah. Diambil dari https://www.academia.edu/8400956/ Muhammadiyah_dan_Kelas_Meneng ah.

Dian Berkah dan Azaki Khoirudin. (2014). Mewujudkan Impian Masyarakat Berkemajuan. Bojonegoro: Nun Pustaka.

F. R. Harahap. (2013, Juni 1). Dampak Urbanisasi Bagi Perkembangan Kota di Indonesia. https://doi.org/10.33019/society.v1i1. 40.

Haedar Nashir. (2010). Muhammadiyah Gerakan Pembaruan. Yogyakarta: Suara Muhammadiyah.

Hery Sucipto. (2010). KH. Ahmad Dahlan: Sang Pencerah, Pendidik, dan Pendiri Muhammadiyah. Yogyakarta: Best Media.

Kuntowijoyo. (2000). Paradigma Islam: Interpretasi untuk Aksi. Yogyakarta: Tiara Wacana.

Kuntowijoyo. (2006). Budaya dan Masyarakat. Yogyakarta: Tiara Wacana.

Lexy J. Moleong. (2000). Metodologi Penelitian Kualitatif. Bandung: Remadja Rosdakarya.
Mohammad Nazir. (1983). Metode Penelitian. Jakarta: Ghalia Indonesia. Mustakim. (2010). Matahari Terbit di Kota Wali: Sejarah Pergerakan Muhammadiyah Gresik 1926-2010. Gresik: Muhi Press.

Soerjono Soekanto. (2006). Sosiologi: Suatu Pengantar. Jakarta: Grafindo Persada.

Syamsul Hidayat. (2012). Tafsir Dakwah Muhammadiyah: Respons Terhadap Pluralitas Budaya. Surakarta: Kafilah Publishing.

Tarjih, M. (Organization) M. (2015a). Model Dakwah Pencerahan Berbasis Komunitas. Yogyakarta: Pimpinan Pusat Muhammadiyah.

Tarjih, M. (Organization) M. (2015b). Tanfidz keputusan Muktamar Muhammadiyah ke-47. Yogyakarta: Pimpinan Pusat Muhammadiyah. 